\title{
LESÃO CORPORAL CULPOSA E A RESPONSABILIDADE PENAL DO MÉDICO: REFLEXÕES À LUZ DA LEI N. 9.099/95
}

CULPABLE INJURY AND CRIMINAL LIABILITY OF DOCTORS: REFLECTIONS UNDER THE LIGHT

OF LAW 9.099/95

\section{Roberto Augusto de Carvalho Campos*}

Paulo Destro**

\begin{abstract}
Resumo:
O presente trabalho é produto de uma reflexão, na dogmática penal brasileira, sobre a atual situação da responsabilidade penal do médico decorrente da prática de ato médico, cuja conduta médica adéqua-se na tipificação do crime de lesão corporal culposa, refletindo-se a aplicação da Lei n. 9.099/95, com considerações e críticas no âmbito do Direito Penal e Processual Penal. Para o desenvolvimento do estudo do tema, foram expostos e analisados, nos seus aspectos gerais, o Direito Penal Médico e a teoria do crime culposo do ato médico.
\end{abstract}

Palavras-chave: Responsabilidade penal do médico - Lei n. 9.099/95.

\begin{abstract}
:
This paper is the result of considerations, in the Brazilian penal dogmatic, about the current situation of criminal liability of doctors when practicing medicine, whose medical conduct fits under the classification of culpable injury crime, reflecting about the application of Law n. 9.099/95, with considerations and review under the scope of Criminal Law and Criminal Procedure Law. In order to develop the subject matter, we exposed and analyzed the Medical Criminal Law, its general aspects and the theory of the wrongful crime of medical practice.
\end{abstract}

Keywords: Criminal liability of doctors - Law n. 9.099/95.

Introdução

No Brasil, não há expressiva literatura jurídica sobre a responsabilidade penal dos médicos, no exercício profissional. Não há, também, estudos e estatísticas do exato número de ações penais, em decorrência de culpa médica. Se, outrora, em nossos tribunais, os processos penais relacionados à responsabilidade médica eram esporádicos e culminavam com a absolvição do profissional médico, atualmente, a situação é alterada, com o aumento dos processos criminais as condenações começam a ser mais frequentes.

Professor Doutor do Departamento de Direito Penal, Medicina Forense e Criminologia da Faculdade de Direito da Universidade de São Paulo.

** Mestre em Direito pela Faculdade de Direito da Universidade de São Paulo. Promotor de Justiça no Estado de São Paulo. 
É sabido quão importante e relevante é o papel dos médicos na estrutura da sociedade atual que, por estar desequilibrada por situações de massas, geram suas próprias doenças, tornando-se necessária a presença da Medicina, essa arte e ciência de evitar ou curar doenças, ou de atenuar seus efeitos.

Apesar da escassa bibliografia específica, a questão da responsabilidade penal dos médicos por eventos lesivos a pacientes é tão antiga quanto o Direito e a Medicina. Atualmente, o tema lesão corporal culposa e a responsabilidade penal do médico: reflexões à luz da Lei n. 9.099/95, tem despertado enorme interesse, em virtude da busca da prestação jurisdicional penal em decorrência do ato médico culposo, por meio de instrumentos processuais com maior efetividade e celeridade.

O Poder Judiciário nacional, em suas várias instâncias, está, a todo instante, deparando-se com procedimentos e processos referentes ao presente tema, o que se deve, por um lado, ao aspecto da Medicina de massa e, por outro, a invocação da prestação jurisdicional, para a responsabilização penal dos médicos.

Serve a presente pesquisa para apresentar, inclusive por razões históricas, a importância desse tema e lançar as bases mais relevantes para a sua compreensão axiológica e o seu sentido finalístico, por meio de encadeamentos visualizadores.

Para atingir os objetivos a que se propõe, observamos que a Medicina nasceu com o aparecimento do primeiro homem neste planeta e da exigência de se obter curas para os seus males corporais e espirituais.

O Direito surgiu da imprescindibilidade de defender o homem contra toda a forma de dominação e violência, pelas normas impositivas precípuas para a convivência e o equilíbrio sociais.

Do ponto de vista histórico, temos a responsabilidade penal médica: no Antigo Oriente; no período clássico da Medicina na Índia, China e Egito; no Direito Greco-romano; na Idade Média e Renascimento; do Iluminismo até o século XIX e no Direito brasileiro.

Também destacamos a eficácia da Medicina contemporânea, associada à área do Direito, na realização de valores na sociedade.

O Direito e a Medicina não são áreas apenas de conhecimento, inteligência ou domínio da técnica; são atividades profissionais que convergem, dentre outros aspectos, em uma relação especial entre as pessoas, na defesa da dignidade humana e da saúde pública ou suplementar.

Desenvolvemos, ainda, no campo referente ao Direito Penal Médico, a contribuição de método interdisciplinar que caminhará para ser, futuramente, com o surgimento de novas práticas médicas, transdisciplinar, jurídico-médico, como novo paradigma que assegure o diálogo produtivo entre as áreas da Medicina e do Direito, face 
às inesperadas e novas situações criadas pela investigação científica, inovação tecnológica, conflitos de interesses e valores que se colocam cada vez mais.

E, assinalamos a necessidade da compreensão, no que for possível, da deontologia médica, o Código de Ética Médica, o ato médico e a responsabilidade penal do médico, que é pessoal, subjetiva, devendo ser comprovada a culpa em cada caso. Assim, os atos praticados pelos médicos que violem o Código de Ética Médica ou qualquer norma que discipline o exercício da Medicina, são de responsabilidade subjetiva, devendo ser apurada a conduta do médico que tenha causado eventual dano.

Ressaltamos, ainda, que deve o profissional da Medicina não apenas perseguir a finalidade de curar, mas também se ajustar às regras da lex artis, estabelecendo como devem ser executados certos atos médicos.

$\mathrm{Na}$ presente pesquisa científica, objetivou-se o estudo da teoria do crime culposo do ato médico, no âmbito da teoria geral do crime, envolvendo a conduta profissional do médico, para fins penais. Analisamos, neste aspecto, a tipicidade, a antijuridicidade, a culpabilidade e a punibilidade. Também, neste capítulo, expomos os relevantes pontos de contato com o bem jurídico, no caso, a integridade física, tutelada concretamente e valorada em nosso ordenamento jurídico.

Para uma melhor análise conjuntural dessas ponderações, que se refletem no Direito Penal, ao tipificar as condutas que violam ou expõem a perigo bens jurídicos de relevante valor social, como a integridade física, torna-se necessário compreender a importância do conceito de culpa no âmbito penal e do conhecimento da lex artis na conduta profissional do médico que se identifique com a malpractice (má prática), que sugestione a responsabilização penal pelo crime de lesão corporal culposa.

Limitamos à análise das principais teorias sobre a licitude do tratamento e ato médico-cirúrgico; o concurso de pessoas no alegado erro médico; a questão do erro, diagnóstico e conduta; além do contributo da teoria do erro humano de James Reason e a segurança do paciente.

Delimitamos as críticas na aplicação da Lei n. 9.099/95, nos crimes de lesão corporal culposa decorrente de ato médico; cuja complexidade da análise jurídica nos fatos relatados insuficientemente em termo circunstanciado, dificulta ou até mesmo impede a consecução dos objetivos originários traçados em sua elaboração legislativa e a responsabilidade penal do médico.

Analisamos a Lei n. 9.099/95 no sistema processual penal brasileiro, em seus diversos aspectos: conceito de infração de menor potencial ofensivo; termo circunstanciado; representação no crime de lesão corporal culposa; pedido de arquivamento do termo circunstanciado; audiência preliminar. Também, foram analisados os institutos da composição civil; transação penal (aspecto constitucional, natureza jurídica da 
proposta e impossibilidade de transação penal ex officio); além da suspensão condicional do processo.

A sociedade brasileira necessita conhecer melhor a aplicação dos dispositivos contidos na Lei n. 9.099/95, refletindo sua incidência em temas da área de saúde; dentre os quais, os relacionados com a integridade corporal, sob uma nova área do conhecimento, o Direito Penal Médico.

1. Revisão da literatura

1.1. Direito Penal Médico

A responsabilidade penal médica vem de tempos de antanho e envolve a reconstituição do passado da ciência médica, desde uma medicina primitiva, como produto de seu tempo, ao longo dos séculos. Tradicionalmente, o exercício da Medicina esteve envolto por uma aura sagrada, justificando o paternalismo clínico, em que o doente sujeitava-se ao médico, sem indagá-lo ou sequer tomar conhecimento do tratamento a ser submetido. Moacyr Scliar, que foi médico e membro da Academia Brasileira de Letras, bem assinala que:

\begin{abstract}
A história da medicina é uma história de vozes. As vozes misteriosas do corpo: o sopro, o sibilo, o borborigmo, a crepitação, e estridor. As vozes inarticuladas do paciente: o gemido, o grito, o estertor. As vozes articuladas do paciente: a queixa, o relato da doença, as perguntas inquietas. A voz articulada do médico: a anamnese, o diagnóstico, o prognóstico. Vozes que falam da doença, vozes calmas, vozes ansiosas, vozes curiosas, vozes sábias, vozes resignadas, vozes revoltadas. Vozes que se querem perpetuar: palavras escritas em argila, em pergaminho, em papel; no prontuário, na revista, no livro, na tela do computador. Vozerio, corrente ininterrupta de vozes que flui desde tempos imemoriais, e que continuará fluindo. ${ }^{1}$
\end{abstract}

De um lado, não se pode compreender a Medicina atual, de forma precisa e profunda, ignorando-se a evolução do conhecimento médico; de outro está "o direito inserido na história, e sua historicidade se manifesta por ser ele reflexo das condições sociais e culturais de uma época."

A responsabilidade penal dos médicos, por atos praticados no exercício da profissão, tem sua origem histórica no Direito da Medicina, ${ }^{3}$ em considerações breves, na

1 SCLIAR, Moacyr. A paixão transformada: história da medicina na literatura. São Paulo: Companhia das Letras 2005. p. 7.

2 REALE JÚNIOR, Miguel. Teoria do delito. 2. ed. rev. São Paulo: Revista dos Tribunais, 2000. p. 15.

3 ESER, Albin. Perspectivas do direito (penal) da medicina. Revista Portuguesa de Ciência Criminal, 
legislação penal das antigas civilizações, onde foram estabelecidas penas específicas para os médicos que causassem lesões corporais a seus pacientes.

A maior parte das compilações de leis da Antiguidade, de origem mística, consideradas como códigos de conduta, surgiram na região da Mesopotâmia.

A responsabilidade médica ${ }^{4}$ já era conhecida nas velhas culturas do Oriente e, através do Código de Ur-Nammu, conhecido, também, como Ley de Ur-Nammu ou Tábuas de Nippur, surgido na Suméria, 2.050 a.C., na região da Mesopotâmia, descoberto em Nippur, em 1952, pelo sumerólogo Samuel Noah Kromer, foi possível identificar, em dois fragmentos de uma tábua, que se encontra no museu de Istambul, um sistema de composição legal em relação às lesões corporais ( $\$ \S 19-22)$, em que o autor da infração devia ressarcir a vítima ou os parentes dela, com uma compensação pecuniária.

O talião ("olho por olho, dente por dente, mão por mão, pé por pé") foi adotado em várias legislações: Código de Hamurabi (Babilônia), Pentateuco (está expressa a origem divina do sistema penal hebraico - dentre os cinco primeiros livros da bíblia, por exemplo, o Êxodo - cap. 23 a 25, e o Levítico - cap. 17 a 21); Kisas (lei de talião nos árabes pré-islâmicos) e Lei das XII Tábuas (Roma Antiga).

Entretanto, no que se refere à responsabilidade penal médica no Código de Hamurabi, nos arts. 215 a 223, em que se disciplina a prática médica e a punição se apresenta como vingança pública, pela melhor interpretação destes dispositivos legais, que necessita ser contextualizada, "os médicos não estavam sujeitos ao talião". ${ }^{6}$

No art. 218 deste antigo estatuto, encontra-se disposto: "Se um médico trata alguém de uma grave ferida com a lanceta de bronze e o mata ou the abre uma incisão com a lanceta de bronze e o olho fica perdido, se lhe deverão cortar as mãos".

E no art. 219: "Se o médico trata o escravo de um liberto de uma ferida grave, com a lanceta de bronze e o mata deverá dar escravo por escravo". ${ }^{7}$

Portanto, pelo disposto no art. 218 do Código de Hamurabi, a pena reservada ao médico revestia-se de rigor: "havendo a morte do paciente resultado de sua atuação,

Coimbra, ano 14, n. 1/2, p. 11-63, jan./jun., 2004.

4 Vide em relação ao surgimento e desenvolvimento histórico da Medicina Legal: ALMEIDA JÚNIOR, A.; COSTA JÚNIOR, J. B. de O. e. Lições de medicina legal. 19. ed. rev. ampl. São Paulo: Companhia Editora Nacional, 1987. p. 13-15.

5 "mas, se houver outros danos, urge dar vida por vida, olho por olho, dente por dente, mão por mão, pé por pé, queimadura por queimadura, ferida por ferida, golpe por golpe": Êxodo, cap. 21, v. 23, BÍBLIA Sagrada. Tradução Centro Bíblico Católico. 65. ed. São Paulo: Ave Maria, 1989. p. 101.

6 MORAES FILHO, Antonio Evaristo de. Aspectos da responsabilidade penal do médico. Revista da Faculdade de Direito da UERJ, Rio de Janeiro, n. 4, p. 289, 1996.

7 NORONHA, Edgard Magalhães. Do crime culposo. São Paulo: Saraiva, 1957. p. 12. 
tinha as mãos decepadas"; 8 pena que se destinava a "evitar que o doutor desastrado repetisse o erro". 9

No caso de insucesso do tratamento, nos termos do art. 219 deste Código, as mãos do médico eram cortadas "se o paciente morto fosse um homem livre, pois se se tratasse de escravo, a sanção consistiria, tão só, em fornecer ao dono, um outro escravo em troca". ${ }^{10}$

Pode-se imaginar, com os meios de então, que o médico realizava cirurgias de extrema simplicidade, em virtude de a anatomia ser pouco conhecida, e com muita serenidade, perícia e máxima atenção preparava sua intervenção, tendo em vista as severas punições de caráter penal que poderia sofrer em caso de insucesso. ${ }^{11}$

A responsabilidade penal médica na Índia, está disposta no Código de Manu, que no art. 695, "atribui o pagamento de multa para médicos e cirurgiões que exerçam mal a sua técnica". ${ }^{12}$

No Egito, a responsabilidade penal médica estava ligada à religião, sendo o médico considerado um sacerdote, dotado de poderes curativos sobrenaturais.

Nos primórdios da prática médica egípcia, em que a saúde, embora de forma limitada, tinha um interesse público e social, ${ }^{13}$ havia um livro denominado Libro Sacro, com regras que deveriam ser respeitadas pelos médicos.

Na Grécia Antiga, a ideia de justiça era extraterrena, pois o "direito e o poder emanavam de Júpiter, o criador e protetor do universo. Dele provinha o poder dos reis e em seu nome se procedia ao julgamento do litígio e a imposição do castigo.”14

8 Nesse sentido: JIMÉNEZ ASÚA, Luís. Tratado de derecho penal. 3. ed. Buenos Aires: Losada, 1976. t. 4, p. 727.

9 SCLIAR, Moacyr. A paixão transformada: história da medicina na literatura. São Paulo: Companhia das Letras 2005. p. 24.

10 MORAES FILHO, Antonio Evaristo de. Aspectos da responsabilidade penal do médico. Revista da Faculdade de Direito da UERJ, Rio de Janeiro, n. 4, 1996. p. 289.

11 Vide, em relação ao sentimento de piedade para com os homens e os animais, que emanavam das normas que disciplinavam a responsabilidade dos médicos e veterinários, no Código de Hamurabi: AZARA, Antonio. Codice di Hammurabi. In: AZARA, Antonio; EULA, Ernesto (A cura di). Novissimo digesto italiano. Torino: UTET, 1967. p. 85.

12 SÁ, Elida Lúcia Batista. Iatrogenia e o erro médico sob a óptica jurídica. Revista de Direito da Defensoria Pública, Rio de Janeiro, ano 7. n. 10, mar. 1997.

13 Nesse sentido, encontramos no Libro Sacro disposições concernentes à higiene na infância, nas habitações, nos sepultamentos de cadáveres. Vide: CASTIGLIONI, Arturo. Storia della medicina. Verona: Mondadori, 1948.

14 NORONHA, Edgard Magalhães. Do crime culposo. São Paulo: Saraiva, 1957. p. 22. Vide sobre a concepção de castigo, justiça e direito de punir: CARRARA, Francesco. Programa do curso de direito criminal: parte geral. Tradução de José Luiz de V. de A. Franceschini e J. R. Prestes Barra. São Paulo: Saraiva, 1956. v. 1. p. 23-24. 
A responsabilidade penal médica era conhecida na Roma Antiga, ${ }^{15}$ pelos relatos de punições aplicadas aos médicos, ao não lograrem o sucesso esperado pelo paciente ou por seus familiares.

$\mathrm{Na}$ responsabilidade penal médica, entre os ostrogodos, o médico que tivesse causado a morte de seu paciente, mesmo não podendo avaliar sua culpa, era deixado aos encargos dos familiares do morto que, desejando, poderiam descarregar sobre o médico, toda a sua raiva e dor.

O Direito Penal canônico, também, exerceu grande influência nessa época, consagrando o princípio de ordem moral ditado pelo Cristianismo. ${ }^{16}$

Entre os séculos $\mathrm{V}$ a XI, em que o saber médico ficou conservado em monastérios, contrasta e sobressai, nesse período histórico, o desenvolvimento experimentado pela Medicina dos árabes e o desenvolvimento da Medicina hebraica, durante o século XII. Se os médicos estavam sujeitos à gravidade das reprimendas penais impostas durante a Idade Média, em decorrência de alegação de erro no exercício da profissão, com o Iluminismo, esse quadro de severidade começou a ser modificado.

No último século, a Medicina sofreu profundas transformações, fruto da incorporação de recursos diagnósticos e terapêuticos inimagináveis ao final do século XIX.

A Medicina alcançou uma eficácia anteriormente imprevista na capacidade de curar, aumentar o tempo de vida e fazer viver melhor. E, muitas melhorias foram aplicações diretas da física, da química e da biologia ao ato médico de cuidar dos enfermos, com o desenvolvimento de esforços na universalização do acesso da população a tais recursos, cada vez mais caros e eficazes.

O reconhecimento pela sociedade dos direitos fundamentais das pessoas repercute nas relações entre os médicos e os pacientes, em âmbito complexo e dinâmico, com destaque para o psicossocial e jurídico. A cada dia que passa, requer-se do profissional da área médica conhecimentos profundos e especializados.

Na evolução histórica da nossa legislação penal, compreendida desde a fase do descobrimento do Brasil até a elaboração do Código Penal de 1940, não é tão notável o interesse pela responsabilização penal do médico.

Durante anos, o ato médico culposo poderia revestir de gravidade adequada para sujeitar o médico à reparação do dano, no juízo cível; vislumbrando-se, no Código Civil de 1916, com segurança, a responsabilidade civil do médico. Contudo, em relação

15 AVECONE, Pio. La responsabilità penale del medico. Padova: Casa Editrice Dott. Francesco Vallardi, 1981. p. 7.

16 Vide: FERRI, Enrico. Princípios de direito criminal: o criminoso e o crime. Tradução de Luiz de Lemos D’Oliveira. 3. ed. Campinas: Russell Editores, 2009. p. 27-28. 
à responsabilidade penal médica, tímida era a evolução da dogmática jurídica brasileira sobre o assunto.

Hoje, é outra realidade e o tema da responsabilidade penal do ato médico coloca-se, cada vez mais, com maior acuidade no contexto jurídico brasileiro.

A responsabilidade penal do médico é fato e existem em nossos Tribunais, diversas ações penais tramitando na apuração de lesão corporal culposa decorrente de ato médico, independente da qualidade ou quantidade do dano produzido e dos fatores que concorreram para o mau resultado.

É inegável a relevância e a importância dos cursos de Direito e Medicina no desenvolvimento e na estrutura da sociedade, sendo imprescindíveis ao progresso social.

O Direito e a Medicina não são áreas apenas de conhecimento, inteligência ou domínio da técnica; são atividades profissionais que convergem, dentre outros aspectos, em uma relação especial entre as pessoas, na defesa da dignidade humana e da saúde pública ou suplementar.

A integração entre as áreas da Medicina e do Direito deve assegurar a dignidade dos seres humanos, valorizando os direitos reconhecidos; potencializando o entrosamento destas áreas no aprimoramento da gestão relacionada à saúde, com a finalidade de atender as necessidades básicas dos indivíduos, considerando a condição socioeconômica de cada um e o respeito ao tratamento igualitário estabelecido em nossa sociedade.

Tal envolvimento revela-se preciso no direito à saúde, fator necessário para o alcance da almejada justiça social, sem distanciar dos princípios da beneficência ${ }^{17}$ integral.

É sabido que a saúde ${ }^{18}$ é um tema que interessa a todos os cidadãos, que estão cientes do seu direito à saúde, cuja importância inicia-se pela sua dignidade constitucional e responsabilização pelo bem-estar do paciente. ${ }^{19}$

Medicina e Direito são criações dos seres humanos que devem ser aproveitadas por estes e, por consequência, ampliem os horizontes do direito à saúde, ${ }^{20}$ com base nas melhores evidências científicas disponíveis.

Não é demais salientar que a área médica sempre guardou particular interesse à ciência penal e, atualmente, o tema da lesão corporal culposa decorrente de

\footnotetext{
17 ALVES, Jeovanna Malena Viana Pinheiro. Ensaios clínicos. Coimbra: Coimbra Ed., 2003. (Faculdade de Direito da Universidade de Coimbra, Centro de Direito Biomédico, 8). p. 16.

18 DIAS, Hélio Pereira. A responsabilidade pela saúde: aspectos jurídicos. Rio de Janeiro: Fiocruz, 1995. p. 5.

19 DIREITO, Carlos Alberto Menezes. Do erro médico. Revista de Direito da Upis, Brasília, v. 2, p. 101-110, set./dez. 2004. p. 13.

20 MONZHEIN, Paul. A responsabilidade penal do médico. Tradução de Alcides Amaral Salles. Revista Justitia, São Paulo, ano 35, v. 81, 2. trim., 1973.
} 
ato médico e a responsabilidade penal nos termos da Lei n. 9.099/95, desperta enorme interesse, devido ao aspecto da Medicina de massa em nosso país e da consciência de cidadania na busca da prestação jurisdicional.

Nos últimos anos, tem-se verificado um grande interesse pelo Direito Penal Médico, cuja dogmática jurídica é cada vez mais aprimorada, traduzindo um interesse pelos problemas da responsabilidade penal do médico.

O Direito se enriquece com os conhecimentos médicos e científicos, que são apreciados pela racionalidade jurídica ou no que concerne à elaboração normativa, em virtude do conhecimento jurídico ser uma das formas principais da experiência humana e ter todo o conhecimento científico, um fundo experimental. ${ }^{21}$

É necessário partir de um pressuposto fundamental, qual seja, que o Direito Penal, instrumento de controle social, "mas de caráter formal e residual, pois só atua diante do fracasso dos instrumentos informais de controle", 22 constitui ramificação da ciência jurídica que é, devendo ser concebido como verdadeira ciência.

Nas concepções tradicionais sobre a ciência penal, sobretudo ao longo do século XIX e, ainda, repercutindo nos dias atuais, temos o Direito Penal relacionandose com um conjunto amplo de disciplinas, tais como, filosofia, teoria geral do direito, história, sociologia, biologia, antropologia, metodologia e com as ciências auxiliares ${ }^{23}$ (Medicina Legal, psiquiatria forense, psicologia judiciária, estatística criminal e polícia científica), ${ }^{24}$ além da criminologia, penologia e política criminal.

Nessa visão tradicional de ciência penal, para o pensamento científico majoritário, o crime torna-se um objeto de uma multiplicidade de ciências.

De acordo com essa tradição jurídica, que se vale da fragmentação e da compartimentalização, encontramos suas raízes no próprio modo como se compreendeu o fazer científico nos últimos séculos; ou seja, para apreender um objeto é necessário dividi-lo em partes e como consequência, perdia-se o todo, na atenção ao detalhe, ao que é particular.

A esse tipo de ciência penal e a esse tipo de trabalho correspondeu um modelo de dogmática jurídico-penal, que resultou na divisão das disciplinas estanques que organizam a metodologia tradicionalmente aplicada. Deu-se isso, possivelmente, pelo

21 TAVARES, Juarez. Teoria do injusto penal. 3. ed. rev. ampl. Belo Horizonte: Del Rey, 2003. p. 3.

22 REALE JÚNIOR, Miguel. Instituições de direito penal: parte geral. 2. ed. Rio de Janeiro: Forense, 2006. v. 1, p. 3 .

23 Vide a Ciência do Direito penal e suas relações com outras disciplinas: MANZINI, Vincenzo. Tratado de derecho penal: teorías generales. Traducción de Santiago Sentís Melendo. Buenos Aires: Ediar Editores, 1948. t. 1, v. 1, p. 3-68.

24 NORONHA, Edgard Magalhães. Direito penal: introdução e parte geral. 24. ed. atual. Adalberto José Q. T. Camargo Aranha. São Paulo: Saraiva, 1986. p. 11-19. 
fato de os pesquisadores não estarem comprometidos em estabelecer limites significativos dentre os vários conhecimentos à época disponíveis.

Os tempos contemporâneos exigem de qualquer Ciência o seu aprimoramento. É o que vemos na Medicina, ampliando de tal monta o conhecimento humano e se desdobrando em vários ramos e inúmeras especialidades, cada vez mais complexas. De outra parte, a ciência penal está em plena discussão metodológica a respeito de seus elementos estruturais. Evidentemente, a tradição dogmática não é isenta de críticas. Desse modo, percebemos que a ciência do direito, vem sofrendo, também, profundas transformações em seus paradigmas com o decurso do tempo.

Uma mudança paradigmática que está em pleno curso, em processo de construção e desenvolvimento nas ciências $^{25}$ e no ensino das ciências. E, com o alargamento do conceito de ciência, há a necessidade de reorganização das estruturas de aprender e ensinar ciências.

É por meio dessa perspectiva que a interdisciplinaridade surge como uma forma de modernização do Direito, adaptando-o aos novos conhecimentos científicos e ao contínuo aperfeiçoamento em todas as suas áreas e, especialmente, o Direito Penal Médico; superando a fragmentação entre as disciplinas, proporcionando um diálogo entre estas, relacionando-as entre si para a compreensão da realidade.

A interdisciplinaridade surgiu para buscar a comunicação entre os campos dos saberes e viabilizar a construção do conhecimento abrangente e articulado da realidade.

Se no campo teórico, a interdisciplinaridade demonstra existência vasta em obras, a sua prática, na área do Direito, ainda é restritiva. É necessário que a interdisciplinaridade não permaneça, apenas, no campo da discussão teórica nas nossas universidades. ${ }^{26}$

O Direito relaciona-se interdisciplinarmente com o conjunto dos problemas universais da própria vida humana, diante de valores e conceitos comuns às mais variadas disciplinas, dentre eles a Medicina, na busca de uma visão mais ampla da realidade e da totalidade do conhecimento.

A Medicina Legal, pela sua característica interdisciplinar, é um rico manancial da maior valia para o Direito Penal e não pode mais ficar afastada dos estudos jurídicos e nem abandonada pelos juristas.

A Medicina sujeita-se a um atuar deontológico, consubstanciado no conjunto de regras de conduta dos médicos, necessárias ao pleno desenvolvimento ético-

25 Vide: MORIN, Edgard. Ciência com consciência. Tradução Maria D. Alexandre e Maria Alice Sampaio Dória. 8. ed. Rio de Janeiro: Bertrand Brasil, 2005.

26 TELLES JUNIOR, Goffredo da Silva. Palavras do amigo aos estudantes de direito: bosquejos extracurriculares, proferidos no escritório do professor em 2002. São Paulo: Juarez de Oliveira, 2003. p. 2-3. 
moral $^{27}$-jurídico ${ }^{28}$ de sua atividade profissional, de modo a zelar pelo seu bom nome e reputação, como também da Medicina, como instituição a que serve.

No Brasil, o exercício da Medicina é regido pelas disposições contidas na Lei n. 12.842, de 10 de julho de 2013, conhecida como Lei do Ato Médico, em que em seu art. $4^{\circ}$, elenca as atividades privativas dos formados em Medicina, dentre as quais: a indicação e execução da intervenção cirúrgica e prescrição dos cuidados médicos pré e pós-operatórios; a indicação da execução e execução de procedimentos invasivos, sejam diagnósticos, terapêuticos ou estéticos, incluindo os acessos vasculares profundos, as biópsias e as endoscopias; a execução de sedação profunda, bloqueios anestésicos e anestesia geral.

Importante destaque a ser analisado no Código de Ética Médica em vigor, se refere à responsabilidade subjetiva do médico, ${ }^{29}$ diante do aumento de processos penais em que se busca a responsabilização penal deste profissional da saúde.

Observamos nas normas de deontologia médica, destinada aos procedimentos éticos em relação a médicos, hospitais e clínicas, pela Resolução do Conselho Federal de Medicina n. 1.931, de 17 de setembro de 2009, o Código de Ética Médica em vigor estabelece no Capítulo I (Princípios Fundamentais), art. $1^{\circ}$ (A Medicina é uma profissão a serviço da saúde do ser humano e da coletividade e será exercida sem discriminação de nenhuma natureza), inciso XIX: $O$ médico se responsabilizará, em caráter pessoal e nunca presumido, pelos seus atos profissionais, resultantes de relação particular de confiança e executados com diligência, competência e prudência.

É sabido que a responsabilidade solidária não se presume; deve decorrer de texto expresso de lei.

Dessa forma, sob a ótica do Código de Ética Médica, cada médico responderá por suas ações ou omissões que caracterizem atos ilícitos, haja vista que a sua responsabilidade é pessoal e subjetiva.

A Medicina é uma atividade cujo exercício obedece as leges artis (as regras, regulamentos ${ }^{30}$ ou leis da arte médica). A violação das leges artis constitui, apenas, um

27 BOBBIO, Norberto. Elogio da serenidade e outros escritos morais. Tradução de Marco Aurélio Nogueira. 2. ed. São Paulo: Ed. Unesp, 2011. p. 49-51.

28 FARIA COSTA, José de. Bioética e direito penal (reflexões possíveis em tempos de incerteza). Coimbra: Coimbra Editora, 2009. v. 1. (Boletim da Faculdade de Direito, Universidade de Coimbra. Ars Ivdicandi. Estudos em Homenagem ao Prof. Doutor Jorge de Figueiredo Dias).

29 Vide, em francês, sobre o tema do ato médico e a responsabilidade penal do médico na Alemanha: JUNG, Heike. Introduction au droit médical allemand. Revue de Science Criminelle et de Droit Pénal Comparé, Paris, v. 1, janv./mars. 1996. Em Portugal: RAPOSO, Vera Lúcia. Do ato médico ao problema jurídico: breves notas sobre o acolhimento da responsabilidade médica civil e criminal na jurisprudência nacional. Coimbra: Almedina, 2013.

30 Roxin denomina as regulamentações, contidas na lex artis, de "normas de tráfico": ROXIN, Claus. Derecho penal: parte general. Madrid: Civitas, 1997. t. 1, p. 1003. 
indício da violação do dever objetivo de cuidado. ${ }^{31} \mathrm{Na}$ prática do ato médico, pode ocorrer de o médico não atuar de acordo com as leges artis e não ter violado o dever objetivo de cuidado na situação concreta; bem como pode acontecer uma violação objetiva de cuidado do médico, ainda que tenha cumprido as leges artis. ${ }^{32}$

Assim, o que deverá ser levado em conta será aferir se o médico, segundo os seus conhecimentos e as suas capacidades pessoais e tendo em conta a sua liberdade na escolha dos meios de diagnóstico e tratamento, encontrava-se em condições de cumprir o dever de cuidado que integra o tipo penal culposo.

\subsection{Teoria do crime culposo do ato médico}

Em linhas gerais, nas últimas décadas, apesar de os profissionais da saúde atuarem condizente com a lex artis, tem-se notado a crescente problemática em nossos tribunais, da responsabilidade penal culposa decorrente do ato médico, ${ }^{33}$ em eventos relacionados às lesões corporais.

Para uma melhor análise conjuntural dessas ponderações, que se refletem no Direito Penal, ao tipificar as condutas que violam ou expõem a perigo bens jurídicos de relevante valor social, como a integridade física, torna-se necessário compreender a importância do conceito de culpa, ${ }^{34}$ no âmbito penal, e do conhecimento lex artis, na conduta do médico que se identifique com a malpractice (má prática), que sugestione a responsabilização penal pelo crime de lesão corporal ${ }^{35}$ culposa.

$\mathrm{Na}$ esfera penal, torna-se importante a análise dos pontos centrais e da estrutura da investigação da culpa na responsabilidade médica (culpa penal médica), especialmente no delito de lesão corporal, ao se atualizar o enfoque da teoria do delito (conduta, tipicidade, antijuridicidade, culpabilidade e punibilidade), do consentimento, e a um aprofundamento da estrutura do injusto no delito culposo, enfrentando-se a questão da responsabilidade penal por omissão médica.

31 Para Welzel, a circunstância em que uma ação contraria um princípio de experiência ou regra da arte, e certamente um sinal, mas não uma prova da lesão do cuidado: WELZEL, Hans. Derecho penal alemán. Santiago de Chile: Jurídica de Chile, 1987. p. 190.

32 ROMEO CASABONA, Carlos María. El médico y el derecho penal I: la actividad curativa (Licitud y responsabilidad penal). Barcelona: Ed. Bosch, 1981. p. 238.

33 Vide: GORANSKY, Mirna. Criterios jurisprudenciales en el ámbito de la imprudencia de la actividad médica. In: MAIER, Julio B. J. (Comp.). Cuestiones particulares de la imprudencia en el derecho penal. Buenos Aires: Ad-Hoc, 1999. p. 119-120.

34 TAVARES, Juarez. Direito penal da negligência: uma contribuição à teoria do crime culposo. 2. ed. rev. e ampl. Rio de Janeiro: Lumen Juris, 2003. p. 3.

35 Interessante a antiga crítica de Alcântara Machado à expressão "lesões corporais", adotada pelo Código Penal: Por que não dizer "lesões pessoais", pois "de todas as denominações encontradas até agora, essa é, por mais expressiva, a mais adequada?” OLIVEIRA, José de Alcântara Machado de. Arquivo de medicina legal e identificação. São Paulo: [s.n.], n. 12, 1935. p. 118. 
O médico, como qualquer outro cidadão, possui direitos e obrigações comuns a todos. No exercício da atividade profissional, o médico e seus auxiliares, como os enfermeiros, tem o dever de agir com diligência e cuidado, conduta exigível de acordo com o desenvolvimento da ciência e das regras consagradas pela prática médica. ${ }^{36}$

É comum, na ordem prática, o médico ser solicitado a intervir e, muitas vezes, cumprir de forma digna sua atuação, despreocupado com a falta de disponibilidade de tempo ou com as condições insatisfatórias para um atendimento objetivo.

Nessas circunstâncias, em situações de emergência ou urgência, com os meios de que dispuser, o médico poderá incorrer, profissionalmente, em negligência (omissão nos cuidados durante o tratamento), ou imprudência (atitude desprovida de cautela que a situação requeria) ou imperícia (ausência ou má aplicação de conhecimentos necessários), tipificando o delito de lesão corporal culposa, objeto desse estudo, no exercício da atividade médica.

Diante de um ato médico cirúrgico que resulte, involuntariamente, numa lesão corporal no paciente, poderemos concluir pela existência, ou não, de um delito, após o estudo deontológico do fato, adequando-se a hipótese delituosa correspondente ao art. $129, \S 6^{\circ}$, do Código Penal, ao sopesarmos os componentes da conduta, tipicidade, antijuridicidade, culpabilidade e punibilidade. ${ }^{37}$

Importante o estudo da teoria do delito ${ }^{38}$ para a compreensão do ato médico, que poderá ser potencial e involuntariamente lesivo à integridade física do paciente, diante do avanço tecnológico registrado nos últimos anos no setor da saúde, com a utilização de modernos e complexos aparelhos associados a sistemas de diagnóstico e de terapia, além do emprego de eficazes, poderosos e agressivos fármacos, substâncias químicas que interagem com os sistemas biológicos, responsáveis, muitas vezes, por efeitos secundários, adversos e irreversíveis.

A atuação do médico, ${ }^{39}$ em seu exercício profissional, incide diretamente em bens tutelados pelo ordenamento jurídico e, especialmente, pelo Direito Penal, tais como, a saúde, a vida, a integridade física e psíquica das pessoas. O estudo do bem jurídico, ${ }^{40}$ na dogmática penal brasileira, exige cautela em sua análise. A função político-criminal do

36 RAPOSO, Vera Lúcia. Do ato médico ao problema jurídico: breves notas sobre o acolhimento da responsabilidade médica civil e criminal na jurisprudência nacional. Coimbra: Almedina, 2013. p. 15-16.

37 GARCIA, Basileu. Instituições de direito penal. 6. ed. São Paulo: Max Limonad, 1982. v. 1, t. 1, p. $213-217$.

38 ZAFFARONI, Eugenio Raúl; PIERANGELI, José Henrique. Manual de direito penal brasileiro: parte geral. 7. ed. rev. e atual. 2. tir. São Paulo: Ed. Revista dos Tribunais, 2008. v. 1, p. 333.

39 CHAIA, Rubén A. Responsabilidad penal médica. Buenos Aires: Hammurabi, 2006. p. 17.

40 Vide o estudo aprofundado do bem jurídico-penal: BECHARA, Ana Elisa Liberatore Silva. Bem jurídicopenal. São Paulo: Quartier Latin, 2014. Vide, também: PASCHOAL, Janaína Conceição. Constituição, criminalização e direito penal mínimo. São Paulo: Ed. Revista dos Tribunais, 2003. p. 25-48. 
bem jurídico constitui um dos critérios principais de individualização e de delimitação da matéria destinada a ser objeto de tutela penal. ${ }^{41}$

O bem jurídico é o reflexo dos valores da estrutura da sociedade em um momento histórico, possuindo um juízo axiológico de significado relevante. O Direito Penal deve agregar à sua base os valores dos bens jurídicos, pois estes consistem no fundamento legitimador da incriminação e do sistema penal como um todo perante a sociedade. Em princípio, a responsabilização penal no exercício da Medicina, ante a complexidade da análise do bem jurídico, não pode surgir se não há um nexo causal entre a conduta do médico e o dano sofrido pelo paciente, ou seja, uma lesão concreta do bem jurídico do delito de lesão corporal culposa, qual seja, a integridade física.

A problemática do ato médico, na condição de ser potencial e involuntariamente lesivo do bem jurídico - integridade física - do paciente, no exercício profissional médico-cirúrgico, individualmente considerado ou em equipes médicas, decorre da análise jurídico-penal da conduta, por ação ou omissão, que resulte no fato típico descrito no art. 129, $\S 6^{\circ}$, do Código Penal brasileiro.

No âmbito da Medicina, devemos analisar e avaliar o ato médico, necessariamente, nas condições de modo, tempo e circunstâncias em que é realizado, em virtude da leges artis de cada patologia, que varia permanentemente, diante dos conhecimentos e descobrimentos na ciência médica, em constante mudança; obrigando o médico a atualizar-se com as técnicas e tratamentos a serem adotados em qualquer patologia.

Apesar de os nossos Tribunais abordarem as questões relacionadas com a responsabilidade penal médica, analisar o ato médico, nas circunstâncias em que é praticado em benefício do paciente, é uma das tarefas mais difíceis; sendo que um dos entraves decorre da maneira de avaliar a conduta profissional do médico, na formação de um juízo conclusivo para eventual repressão penal.

Do ponto de vista jurídico-penal, a conduta humana é a pedra angular ${ }^{42}$ da teoria do delito, ${ }^{43}$ em que se formulam todos os juízos que compõem o conceito de crime: tipicidade, antijuridicidade, culpabilidade e punibilidade.

${ }_{41}$ Nesse sentido: SALVADOR NETTO, Alamiro Velludo. Finalidades da pena: conceito material de direito e sistema penal integral. São Paulo: Quartier latin, 2009. p. 37-45.

42 Para Engisch, a conduta é a pedra angular de toda a sistemática da teoria do delito: ENGISCH, Karl. Der finale Handlungsbegriff. In: BOCKELMANN, Paul et al. (Ed.). Probleme der Strafrechtserneuerung: Festschrift für Eduard Kohlrausch. Berlin: Walter de Gruyter, 1944. p. 143. Vide, também: PETROCELLI, Biaggio. Principi di diritto penale. Napoli: Jovene, 1964. t. 1. p. 247.

43 FRAGOSO, Heleno Cláudio. Lições de direito penal: parte geral. 17. ed. atual. Fernando Fragoso. Rio de Janeiro: Forense, 2006. p. 173. 
Os médicos, em respeito ao dever hipocrático de tratar e interceder ativamente pela preservação da vida, empenham-se na aplicação dos seus conhecimentos e experiência no combate permanente contra a doença e a morte, constituindo nessas circunstâncias, a leges artis na "pedra angular da atividade médico-curativa". ${ }^{44}$

O Direito Penal não cria o conceito de conduta, ${ }^{45}$ mas o retira do mundo fenomênico dos fatos. Ainda que não houvesse o Direito, certamente que se realizariam as condutas.

Desta forma, no âmbito da responsabilidade penal, a leges artis compreende as ações ou omissões que o médico desenvolve na preservação da integridade física do paciente, diante dos meios e técnicas utilizadas na elaboração do diagnóstico ou na terapia a ser adotada ou no ato cirúrgico a ser realizado. ${ }^{46}$

As modalidades de conduta humana são a ação e a omissão, sendo que o termo genérico ação ${ }^{47}$ é, muitas vezes, compreendido como sinônimo de conduta; razão pela qual, doutrinariamente, o termo ação envolve a comissão, identificando uma ação positiva $e$, a omissão, identificando uma ação negativa.

Por isso, acode-nos sempre à mente, a necessidade de ter presente, em cada caso concreto de atividade médica, com destaque para as equipes médicas interdisciplinares, a problemática do ato médico cirúrgico, como potencial e involuntariamente lesiva do bem jurídico "integridade física", decorrente de condutas, por ação ou omissão, que deverão ser aferidas pelo cumprimento das leges artis, na avaliação da conduta, de acordo com os critérios e limites valorativos que emergem dessa lex, para efeitos de responsabilidade penal no domínio jurídico-penal.

As fronteiras do Direito Penal médico alargam-se gradativamente, principalmente na responsabilidade penal dos médicos ${ }^{48}$ e seus auxiliares, ao causarem, culposamente, uma ofensa corporal em que não tenha sido conduzida de acordo com a legis artis, no âmbito do concurso de pessoas no alegado erro médico e, em especial, nas equipes médicas envolvendo multiprofissionais.

44 RODRIGUES, Álvaro da Cunha Gomes. A negligência médica hospitalar na perspectiva jurídico-penal: estudo sobre a responsabilidade criminal médico-hospitalar. Coimbra: Almedina, 2013. p. 40.

45 PIERANGELI, José Henrique. Escritos jurídico-penais. 3. ed. rev. atual. e ampl. São Paulo: Ed. Revista dos Tribunais, 2006. p. 15.

46 Idem. O consentimento do ofendido: na teoria do delito. 3. ed. rev. e atual. São Paulo: Ed. Revista dos Tribunais, 2001, p. 194-195.

47 BRUNO, Aníbal. Direito penal: parte geral - introdução, norma penal, fato punível. 5. ed. rev. atual. Raphael Cirigliano Filho. Rio de Janeiro: Forense, 2005. t. 1, p. 190-191.

48 GÓMEZ RIVERO, Maria Del Carmen. La responsabilidad penal del médico. 2. ed. Valencia: Tirant lo Blanch, 2008. p. 15. 
A problemática do alegado erro médico e as suas consequências na análise do bem jurídico - integridade física - e saúde do paciente é antiga; constituindo-se, atualmente, numa realidade incontestável.

Assim, o alegado erro médico é tema inerente à própria atividade médica. O fluxo noticioso sobre tal tema na mídia, com expressiva informação sobre casos envolvendo o intitulado erro médico, são abordados pela imprensa escrita e televisiva ${ }^{49}$ sem qualquer rigor terminológico, promovendo o descrédito de médicos, cuja profissão é regulamentada em lei.

Tradicionalmente, do ponto de vista jurídico-penal, o erro é a falsa representação da realidade, isto é, "o erro constitui uma representação não correspondente à realidade, uma representação falsa da realidade fática ou normativa". ${ }^{50}$ Não obstante esta axiomática verdade, a temática do alegado erro médico não tem merecido um enfoque devido no âmbito do Direito Penal Médico.

É de toda conveniência ter em mente que o erro não se confunde com a ignorância e seus efeitos jurídicos ${ }^{51}$ não podem ser tratados da mesma forma.

É necessária a conceituação de erro médico para estudar o fenômeno em suas vertentes técnicas, decifrando sua epidemiologia, diante do que representa, significa e repercute o mau resultado no exercício da profissão médica e sua responsabilização jurídico-penal. A definição de erro médico, que se tornou clássica, foi emitida em 1939, por Eberhard Schmidt, médico e penalista alemão, qual seja, "Todo o erro, cometido por um médico durante a assistência a um doente, deve ser aqui abordado como sendo um 'erro profissional"', 52

Vislumbra-se, por esse conceito clássico, que nem todo alegado erro médico, analisado como falha ou "erro profissional", assume relevância jurídico-penal, tipificando um ilícito penal. Um erro do ponto de vista técnico ou um procedimento errado, constitui um fato, sem qualquer valoração jurídica, podendo ser, em determinadas situações, insignificante no âmbito penal. ${ }^{53}$

Não há uma uniformidade no Direito Penal Médico, das definições envolvendo o alegado erro médico, ${ }^{54}$ que recai sobre o universo dos atos e conduta médica.

\footnotetext{
49 ANTUNES, João Lobo. Um modo de ser. 12. ed. Lisboa: Gradiva Publicações, 2003. p. 77.

50 REALE JÚNIOR, Miguel. Instituições..., p. 200.

51 TOLEDO, Francisco de Assis. Erro no direito penal. São Paulo: Saraiva, 1977. p. 1-4.

52 "Jeder dem Arzt in der Arbeit am Kranken unterlaufenden Fehler soll hier also als 'Kunstfehler' angesprochen werden" SCHMIDT, Eberhard. Der Arzt im Strafrecht. Leipzig: Verlag von Theodor Weicher, 1939. p. 138.

53 ARIAS MADRIGAL, Doris. La responsabilidad penal en el ámbito médico sanitario: algunas consideraciones generales. Revista de la Asociación Española de Ciencias Penales, Madrid, v. 2, n. 1, p. 88, 1999.

54 Na doutrina especializada, diversos são os conceitos de erro médico. Saliente-se, o estudo do psicólogo cognitivo James Reason, professor de psicologia da Universidade de Manchester e membro da Sociedade
} 
No Brasil, Irany Novah Moraes, professor da Faculdade de Medicina da Universidade de São Paulo, conceitua erro médico nos seguintes termos: "a ação ou omissão do médico que, no exercício profissional, causa dano à saúde do paciente". ${ }^{55}$

Nos dias atuais, a queixa mais frequente que circula no âmbito do Direito Penal Médico é, sem dúvida nenhuma, a que diz respeito ao intitulado erro ${ }^{56}$ médico, ou seja, da falha do médico no exercício da profissão.

Na determinação da responsabilidade penal culposa no exercício da Medicina em equipe, torna-se imprescindível nas intervenções e tratamentos médico-cirúrgicos, a análise da viabilidade da questão do concurso de pessoas, isto é, a possibilidade da associação de dois médicos ou de outros profissionais da equipe médica, concorrendo para a execução de um evento criminoso, em sua modalidade culposa, em violação ao dever de cuidado, originando ou potenciado uma situação que possa concretizar-se numa ofensa ao corpo.

Nos últimos anos, as organizações e agências internacionais de saúde têm destacado a necessidade de ampliar estratégias direcionadas para melhorar a qualidade do cuidado à saúde e, consequentemente, atenuar os riscos inerentes a segurança dos pacientes. ${ }^{57}$ Ao longo desse período, desenvolveram-se pesquisas para a segurança do paciente, diante de um número significativo de eventos adversos resultantes de alegados erros médicos.

A segurança do paciente, um importante aspecto da qualidade em saúde, se tornou foco de atenção a partir do relatório intitulado To err is human - "Errar é humano" - apresentado pelo Institute of Medicine (IOM) ${ }^{58}$ dos Estados Unidos da América, em 1999, relacionado ao estudo da prática médica de Harward (HMPS), que apontou a alta frequência de eventos adversos resultantes do cuidado hospitalar.

A partir de então, foi criada pelo governo americano e fundadores do IOM, a Agency for Healthcare Research and Quality (AHRQ), com a missão de melhorar a qualidade, a segurança, a eficiência e a efetividade do cuidado à saúde para os americanos,

Britânica de Psicologia, sobre o erro: "Error será el término genérico utilizado para englobar todas aquellas ocasiones en las que una secuencia planificada de actividades mentales o físicas no logra alcanzar el resultado deseado, y cuando este fracaso no pueda ser atribuido a la intervención del azar." REASON, James. El error humano. Madrid: Modus Laborandi, 2009. p. 35.

55 MORAES, Irany Novah. Erro médico. 2. ed. ampl. São Paulo: Ed. Santos-Maltese, 1991, p. 35.

56 LEME, Pedro de Alcântara da Silva. O erro médico e suas implicações penais e civis. Revista Brasileira de Ciências Criminais, São Paulo, ano 1, n. 1, p. 121-122, jan./mar. 1993.

57 Para a Organização Mundial da Saúde (OMS), segurança do paciente "corresponde à redução ao mínimo aceitável do risco de dano desnecessário associado ao cuidado de saúde." RUNCIMAN, W. et al. Towards an international classification for patient safety: key concepts and terms. Int. J. Qual Health Care, v. 21, n. 1, p. 21, 2009.

58 CORRIGAN, Janet M.; DONALDSON, Molla S.; KOHN, Linda T. To err is human: building a safer health system. The Institute of Medicine (IOM). Washington, D.C: National Academy Press, 1999. 
descrevendo práticas médico-hospitalares mais seguras relacionadas à diminuição dos danos causados aos pacientes.

A teoria sobre o erro humano, produto da extensa pesquisa realizada por James Reason, foi apresentada no ano de 1990, pela publicação do livro Human error, em que faz uma análise profunda do tema, transcendendo a mera descrição de princípios gerais sobre a ocorrência e tipos de erros.

Ao observar os acidentes organizacionais, James Reason buscou uma explicação lógica para esses fenômenos e demonstrou que todo acidente organizacional é originário do rompimento de barreiras e proteções que separam os perigos e os danos às pessoas, denominados de perdas, conforme figura abaixo.

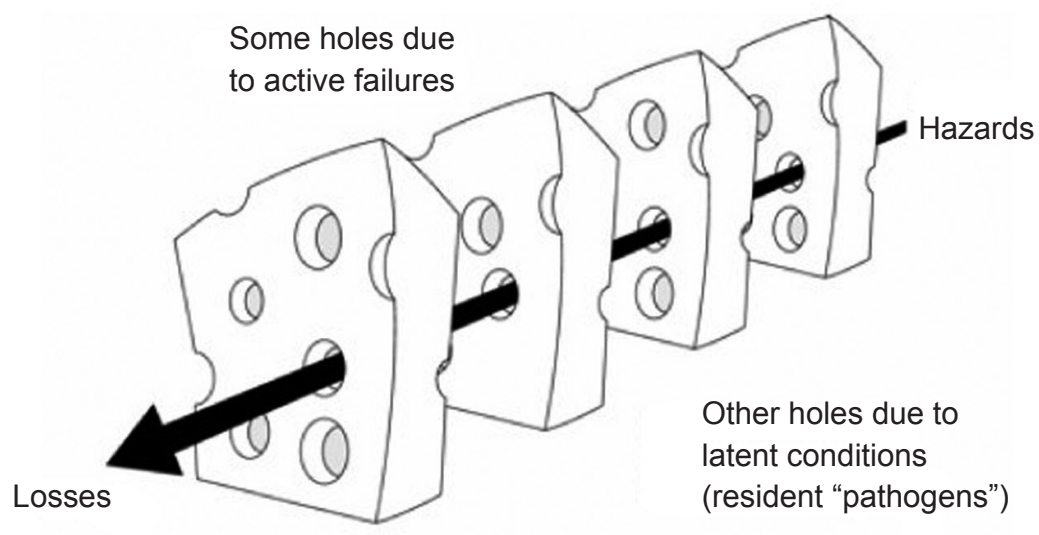

Successive layers of defences, barriers and safeguards

Figura 1. O modelo epidemiológico descreve o acidente por meio de uma analogia à saúde do sistema (acidentes são gerados da mesma forma que a doença) e a um "Queijo Suíço": as defesas, barreiras e salvaguardas (layers of defences, barriers and safeguards) podem ser penetradas, como se vê pela seta, por perigos (hazards) ocasionando danos, denominados de perdas (Losses). Estas barreiras são continuamente rompidas por falhas ativas (cometidas pelos operadores, geralmente situados no final da cadeia dos eventos, com consequências imediatas) e latentes do sistema (são condições estruturais que, embora não tenham consequências imediatas, estão sempre presentes no sistema, aguardando um fator desencadeador para serem percebidas).

Neste contexto, o modelo do "Queijo Suíço”, proposto em 1990, por James Reason, está baseado em defesas, barreiras e salvaguardas que, na maioria das vezes, 
funcionam bem, mas sempre existem deficiências. As medidas de segurança baseiam-se no fato de que não podemos mudar a natureza humana, mas sim as condições sob as quais os seres humanos trabalham. Quando um evento adverso ocorre, o importante não é quem cometeu o erro, mas sim como e porque as defesas falharam.

Em um contexto hipotético, cada camada de defesa, barreira ou salvaguarda deveria estar íntegra, entretanto, via de regra, apresentam-se como "fatias de um queijo suíço", cheias de buracos.

Contudo, de forma diferente do queijo, esses buracos estão continuamente se abrindo e fechando em diferentes momentos. Tais buracos, em uma camada, são inofensivos, mas quando ocorre um alinhamento destes buracos nas diferentes camadas do sistema de defesas, barreiras ou salvaguardas, ocorre a possibilidade de ocorrência de um evento perigoso, conforme figura abaixo.

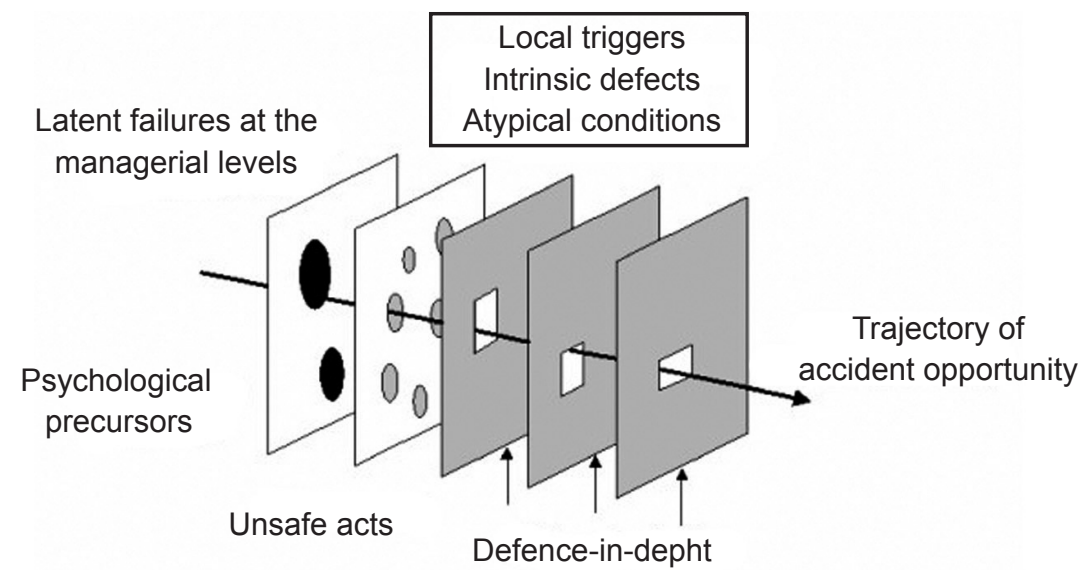

Figura 2. Dinâmica das causas dos acidentes, mostrando uma trajetória de oportunidade de acidente (trajectory of accident opportunity) que se origina nos níveis superiores do sistema e penetra em vários sistemas defensivos, passando pelos planos da condição prévia e ato inseguro (psychological precursors - unsafe acts) e através de três capas sucessivas de defesas em profundidade (defence-in-depth). Isto provoca uma complexa interação entre os erros e uma variedade de eventos desencadeantes locais (local triggers - intrinsic defects - atypical conditions). Os buracos nas defesas surgem por duas razões: falhas ativas e condições latentes. A figura reflete claramente que a probabilidade de a seta (trajetória) encontrar buracos, em todas as camadas de defesas, no mesmo momento, é muito pequena. 
Neste cenário dinâmico, o trabalho na área de saúde caracteriza-se como relacional, pela interação entre os profissionais da área médica, paciente e tecnologia, sendo que o resultado desse trabalho é influenciado pela característica do procedimento, do ambiente onde está sendo realizado e do contexto organizacional.

Nessas circunstâncias, deve-se ter cautela na questão da responsabilização penal do médico, muitas vezes, diante das fragilidades e deficiências nas barreiras de defesas do sistema de saúde por inteiro. É uma questão a ser repensada, pois a análise da culpa, por si só, na condução de julgar ${ }^{59}$ o alegado erro médico é feita de maneira superficial, o que impede a utilização de uma estratégia correta e eficaz para melhorar a segurança do paciente.

\subsection{Lesão corporal culposa e a responsabilidade penal do médico na Lei n. 9.099/95}

Desde o início do século XX, eram buscadas alterações no sistema processual penal, à procura de instrumentos que garantissem a efetividade ${ }^{60}$ do processo e sua instrumentalidade.

Os institutos fundamentais do direito processual, tais como a jurisdição, a ação, defesa e processo, desafiavam os doutrinadores sob um enfoque interdisciplinar, visando à desburocratização da Justiça, já que o enorme número de delitos de ínfima expressão resultava em diminuição de tempo para investigação policial e julgamento das infrações de maior gravidade, implicando tardia resposta do Poder Judiciário, que tanto tem contribuído para agravar o sentimento de impunidade que assola a sociedade.

A origem legislativa dos Juizados Especiais no ordenamento jurídico brasileiro está capitulada no art. 144, § $1^{\text {o }}$ alínea “b”, da Constituição de 1967, sendo que a regulamentação do referido dispositivo constitucional deu-se dezessete anos depois, em 7 de novembro de 1984, pela Lei n. 7.244, com a criação dos Juizados Especiais de Pequenas Causas.

No âmbito do sistema formal de controle social, a ânsia por alterações estruturais no processo penal e a ineficiência das formas usuais de tutela jurisdicional, muitas vezes, com o cumprimento de solenidades processuais, contribuíram, aliada à morosidade da Justiça relacionada, o aumento do índice da criminalidade, o sentimento de insegurança nos grandes aglomerados urbanos e a pressão da opinião pública amplificada pelos meios de comunicação de massa, para a ideia de uma resposta judicial penal mais

$59 \quad$ REASON, James. op. cit., p. 295-296.

60 DOTTI, René Ariel. Conceitos e distorções da Lei n. 9.099/95 - temas de direito e processo penal. In: PITOMBO, Antonio Sérgio A. de Moraes (Org.). Juizados especiais criminais: interpretação e crítica. São Paulo: Malheiros Ed., 1997. p. 34. 
célere, mas com a preservação da segurança jurídica, em que o legislador buscasse outras sanções alternativas à pena de prisão.

A Lei n. 9.099/95, de 27 de setembro de 1995, ${ }^{61}$ teve uma acolhida favorável da parte de quase todos os operadores do Direito Penal e Processual Penal, sendo recebida com simpatia e discursos entusiásticos, com a reação favorável ao seu texto e à nova proposta de justiça criminal para os crimes de menor potencial ofensivo, inovando nosso sistema processual-penal; não obstante muitos dos seus pontos terem sido severamente questionados por expoentes de nossa doutrina. Cumprindo determinação estabelecida no art. 98, inciso I, da Constituição Federal de 1988, o legislador instituiu os Juizados Especiais Cíveis e Criminais, criando o procedimento sumaríssimo, para as infrações penais de menor potencial ofensivo.

No que se refere ao tratamento dispensado ao crime de lesão corporal culposa, passou a exigir a via despenalizadora indireta da representação para se instaurar a ação penal, nos crimes de lesão corporal leve e culposa; introduzindo no sistema processual-penal brasileiro, a composição cível, transação penal e a suspensão condicional do processo. De modo a debelar a morosidade na resolução de conflitos da sociedade brasileira, sendo perceptível há muito tempo que "os mecanismos processuais também já não conseguem exercer de maneira eficaz seu papel de absorver tensões, dirimir conflitos, administrar disputas e neutralizar a violência", ${ }^{62}$ criaram-se os Juizados Especiais Criminais (JECrim), pela Lei n. 9.099/95.

Tais Juizados foram concebidos com o objetivo de resgatar o prestígio e a credibilidade da Justiça penal, atendendo aos hodiernos clamores da sociedade no combate à criminalidade e à impunidade; ou seja, com a aparente finalidade de dar efetividade à norma penal.

Esse diploma é considerado por muitos, como um avanço no campo da Justiça Criminal, na medida em que o legislador demonstrou preocupação com a vítima, objetivando, sempre que possível, a reparação dos danos sofridos, no qual se abre um espaço para o consenso e acesso mais direto da população aos órgãos judiciais, com rápida solução jurisdicional e pronta aplicação da pena, nas infrações penais de menor potencial ofensivo.

É o que vemos, por exemplo, no crime de lesão corporal culposa decorrente de ato médico, dando-se ênfase na reparação de danos eventualmente causados à vítima (paciente) pelo autor dos fatos (neste trabalho, nos referimos ao médico) e à aplicação

\footnotetext{
${ }_{61}$ Vide, em relação à origem da Lei n. 9.099/95 e o trâmite legislativo: GRINOVER, Ada Pellegrini; GOMES FILHO, Antônio Magalhães; FERNANDES, Antônio Scarance; GOMES, Luiz Flávio. Juizados especiais criminais: comentários à Lei 9.099, de 26.09.1995. São Paulo: Ed. Revista dos Tribunais, 1996. p. 25-29.

62 FARIA, José Eduardo. As transformações do direito. Revista Brasileira de Ciências Criminais, São Paulo, ano 6, n. 22, p. 231, abr./jun., 1998.
} 
de medidas alternativas à pena de prisão, com a adoção de um procedimento ágil, orientando-se por princípios informativos do JECrim, na tentativa de se obter, se possível, a conciliação (composição cível) ou a transação penal.

A Constituição Federal de 1988 não definiu o que são infrações de menor potencial ofensivo, incumbência destinada à legislação ordinária. De fato, com consideráveis mudanças na aplicação do Direito Penal e Processual Penal, com a vigência da Lei n. 10.259/2001, consideram-se infrações de menor potencial ofensivo, os delitos (contravenções penais e crimes) a que a lei comine pena máxima não superior a dois anos, ou multa.

Diante disso, consideramos que o legislador, na elaboração da Lei n. 10.259/2001, adotou critério de natureza penal (quantidade da pena cominada), ao incluir nas infrações de menor potencial ofensivo, as contravenções penais e, os crimes a que a lei determina que o máximo da sanção detentiva não seja superior a dois anos, cumulada ou não com multa, nos termos da Lei n. 11.313/2006.

O termo circunstanciado é um documento elaborado pela autoridade policial com o escopo de substituir o inquérito policial, especificamente, nas ocorrências em que for constatada infração de menor potencial ofensivo.

Indispensável, na elaboração do termo circunstanciado, o resumo das versões do autor do fato e vítima, com a apresentação do rol de testemunhas, com a súmula do que tiverem presenciado e, se possível, na apuração do crime de lesão corporal culposa, o colhimento na fase policial da representação da vítima, nos termos do art. 88, da Lei n. 9.099/95. Ao autor do fato que, após a lavratura do termo circunstanciado, for imediatamente encaminhado ao Juizado Especial Criminal ou assumir o compromisso de a ele comparecer, não se imporá prisão em flagrante, nem se exigirá fiança, conforme disposto no art. 69, parágrafo único, da Lei n. 9.099/95.

Com efeito, colocada a questão sob esse ângulo, a edição da Lei n. 12.403, de 04 de maio de 2011, alterou dispositivos do Código de Processo Penal relativos à prisão em flagrante, fiança, liberdade provisória e demais medidas cautelares, com o objetivo de evitar o encarceramento antes de transitar em julgado a sentença penal condenatória, tornando inviável, desnecessária e desproporcional a prisão em flagrante do autor do fato, mesmo com a sua recusa em assumir o compromisso de ir a juízo, apesar do disposto no art. 69, parágrafo único, da Lei n. 9.099/95.

Com a superveniência da Lei n. 9.099/95, o início da ação penal no crime de lesão corporal culposa, até então instaurável mediante ação penal pública incondicionada, passa a se subordinar à exigência formal da representação da vítima. 
A representação da vítima, no contexto da Lei n. 9.099/95, constitui uma delatio criminis postulatória, isto é, "quem a formula, não só dá notícia de um crime, como pede também que se instaure a persecução penal". ${ }^{63}$

A representação constitui, nos casos expressamente previstos em lei, a condição de procedibilidade para que o Ministério Público inicie a ação penal. Desta forma, a representação é um elemento subordinante da atividade de persecução penal desenvolvida pelo Estado.

O próprio ajuizamento da ação penal, pelo Ministério Público, está condicionado à manifestação inequívoca da vítima, pela petição escrita ou oral (tomada por termo), não se exigindo qualquer formalidade, no prazo decadencial.

A autoridade policial que tomar conhecimento, em sua circunscrição territorial, do crime de lesão corporal culposa, decorrente de ato médico, lavrará termo circunstanciado e o encaminhará ao Juizado Especial Criminal (JECrim), ${ }^{64}$ providenciando as declarações da vítima ou de seu representante legal, testemunhas e suposto autor do fato (médico) e as requisições dos exames de corpo de delito ${ }^{65}$ e outras periciais necessárias, visando a elucidação do fato e suas circunstâncias, coligindo dados a respeito na natureza da infração penal.

A autoridade policial, responsável pela investigação do fato típico, não pode arquivar termo circunstanciado, ainda que haja elementos da existência de causa excludente de antijuridicidade ou de culpabilidade, o que é atribuição do Juiz a pedido do representante do Ministério Público. Remetidos o termo circunstanciado à autoridade judiciária, esta providenciará o encaminhamento dos autos ao membro do Ministério Público, o titular da ação penal, órgão do Estado incumbido da persecução em juízo, mediante representação da vítima.

Ao analisar o termo circunstanciado, poderá o Promotor de Justiça tomar uma das seguintes providências: a) requerer o arquivamento do termo circunstanciado; b) requerer a extinção da punibilidade, devendo observar se a representação foi exercida pela vítima, ou seu representante legal, no prazo decadencial de seis meses, contado do dia em que vier a saber quem é o autor do crime, nos termos do art. 38, do Código de Processo Penal; c) requerer a devolução dos autos de termo circunstanciado à Polícia para a juntada de laudos periciais ou diligências imprescindíveis ao oferecimento da ação penal.

\footnotetext{
63 MARQUES, José Frederico. Elementos de direito processual penal. 2. ed. Rio de Janeiro: Forense, 1965. v. 1, p. 344.

${ }^{64}$ Nas Comarcas em que não foram instalados os JECrim, os autos de termo circunstanciado serão remetidos para os Cartórios das Varas Criminais.

65 ALMEIDA JUNIOR, João Mendes. O processo criminal brazileiro. 3. ed. Augmentada. Rio de Janeiro: Typ. Baptista de Souza, 1920. v. 2, p. 7-10.
} 
A prática de devolução dos autos de termo circunstanciado à Polícia contraria o princípio da celeridade, estabelecido no art. $2^{\circ}$, da Lei n. 9.099/95, em que se almeja buscar com rapidez a prestação jurisdicional. Entretanto, é sabido da precariedade dos depoimentos constantes destes termos circunstanciados ou dos resumos das versões da vítima, suposto autor do fato e, eventuais testemunhas, o que dificulta e até mesmo impossibilita a formação da opinio delicti do membro ministerial.

Acrescente-se a isso, a necessidade para a existência de indícios da autoria e materialidade, no crime de lesão corporal culposa, da realização imprescindível do exame de corpo de delito, que pode ser direto (o perito examina os vestígios deixados pelo crime - ou seja, o corpo de delito); ou complementar, em virtude de questionamentos formulados pela autoridade policial ou partes envolvidas neste conflito de interesses; ou indireto, na impossibilidade absoluta de ser feito o exame direto, permitindo-se prova testemunhal para suprir-lhe a falta.

Nessas circunstâncias, nas Comarcas em que há JECrim instalados, o Juiz deve concordar com o requerimento ministerial, em manifestação devidamente fundamentada, com a remessa dos autos à delegacia de polícia, para que a autoridade policial complete ou esclareça o conteúdo do termo circunstanciado, por serem diligências imprescindíveis ao oferecimento da ação penal, com a necessária colaboração da Medicina Legal, ciência auxiliar valiosa no esclarecimento de certos fatos para os fins do processo penal, na elaboração de laudos periciais.

Não sendo o caso de arquivamento dos autos de termo circunstanciado, em nosso sistema processual penal, é dever do Ministério Público requerer ao Juiz a designação de audiência preliminar, presentes as condições da ação penal pública condenatória, de maneira a exercer a pretensão punitiva, observando-se os princípios constitucionais processuais, para fins, inicialmente, de conciliação, pela composição civil (nos crimes de lesão corporal culposa).

Se inviável a conciliação ou a composição civil, ${ }^{66}$ poderá ${ }^{\square}$ Promotor de Justiça oferecer a proposta de transação penal. O procedimento perante os Juizados Especiais Criminais (JECrim) pode, nos crimes de lesão corporal culposa, desenvolver-se em uma ou duas fases, quais sejam: a audiência preliminar (envolvendo a composição civil ou sendo frustrada, a aplicação de transação penal) e o procedimento sumaríssimo.

A audiência preliminar, uma das principais novidades advindas da Lei n. 9.099/95, consiste, inicialmente, em uma audiência de conciliação, nos crimes de lesão

66 $\quad$ Art. 75, da Lei n. 9.099/95: "Não obtida a composição dos danos civis, será dada imediatamente ao ofendido a oportunidade de exercer o direito de representação verbal, que será reduzida a termo. Parágrafo único. O não oferecimento da representação na audiência preliminar não implica decadência do direito, que poderá ser exercido no prazo previsto em lei." 
corporal culposa, decorrente de ato médico, conduzida pelo Juiz, com a presença do representante do Ministério Público, autor do fato e vítima.

Nesta audiência preliminar, mediante intimação, presente o suposto autor do fato (médico) e a vítima, acompanhados de advogados ou de Defensor Público, poderão ocorrer três hipóteses previstas na Lei n. 9.099/95: a composição civil dos danos; a transação penal; oferecimento oral de denúncia pelo representante do Ministério Público.

Na sistemática da Lei n. 9.099/95, o instituto da composição dos danos civis ${ }^{67}$ versa sobre objeto de natureza patrimonial disponível e possui natureza despenalizadora.

Tal instituto insere-se no modelo que prestigia a vítima, trazendo a reparação do dano para o processo penal.

A fase judicial inicia-se com a audiência preliminar, na qual o Juiz esclarecerá, primeiramente, sobre a possibilidade da composição civil dos danos, interpretada como conciliação, em que há a possibilidade de o médico (suposto autor do fato) e a vítima, orientados por seus defensores, transigirem na reparação dos danos materiais e morais, cujo acordo terá eficácia de título executivo judicial, após a homologação do Juiz que preside a audiência, com a consequente renúncia ao direito de representação da vítima, extinguindo-se a punibilidade do autor do fato, nos termos do art. 107, inciso V, do Código Penal.

Entretanto, não obtida a conciliação ou a composição dos danos na audiência preliminar, será dada à vítima a oportunidade de exercer verbalmente ou ratificar o direito de representação, manifestado ou requerido por escrito na elaboração do termo circunstanciado.

Frustrada a composição civil e a vítima representando, o Promotor de Justiça poderá oferecer a proposta de transação penal.

A Lei n. 9.099/95 introduziu algumas modificações no sistema ${ }^{68}$ processual penal brasileiro, pela criação do denominado espaço de consenso.

E um dos seus institutos inovadores ainda permanece polêmico: a transação penal, instituto novo e sem precedentes na história processual penal brasileira, cuja interpretação dos seus dispositivos normativos é controversa.

Confrontando as previsões legais com a realidade empírica de um novo modelo de Justiça penal, na análise da aplicação desse novel instituto, é de extrema relevância na investigação da lesão corporal culposa decorrente de ato médico, as implicações da adoção da transação penal ao considerado autor do fato (médico), segundo as regras de processo penal constitucional, sob pena de ferir direitos e garantias legalmente assegurados.

\footnotetext{
${ }_{67}$ Alguns doutrinadores utilizam a expressão transação civil.

68 JARDIM, Afrânio Silva. Direito processual penal. 11. ed. Rio de janeiro: Forense, 2007. p. 335.
} 
A transação ou composição penal, introduzida pela Lei n. 9.099/95, no direito brasileiro, de sorte a concretizar o comando contido no art. 98, inciso I, da Constituição Federal de 1988, mudou profundamente o panorama do sistema processual penal, ao institucionalizar o acordo penal, delimitando e prescindindo por completo da prova, e não está imune a questionamentos acerca de sua constitucionalidade.

É imprescindível tecer algumas considerações sobre a transação penal que admite a aplicação imediata de pena restritiva de direitos ou multa, sem a adoção de um procedimento de apuração da culpabilidade do suposto autor do fato (médico) -, ressaltando a repercussão que o novo instituto angariou entre os operadores do direito, não obstante muitos de seus pontos receberem severas críticas por expoentes de nossa doutrina, com discussões referentes à constitucionalidade desse instituto, da atuação dos Juizados Especiais Criminais - JECrim, dentre outros aspectos.

Para uma minoria de doutrinadores, esse instituto é inconstitucional, em virtude de não atentar para alguns princípios constitucionais, ${ }^{69}$ dentre os quais, devido processo legal, ampla defesa, contraditório e presunção de inocência.

Contemplada na Lei dos Juizados Especiais Criminais, a proposta de transação penal oferece a possibilidade ao suposto autor do fato da prática de uma infração de menor potencial ofensivo sujeitar-se à pena restritiva de direitos ou multa, por um acordo com o Ministério Público, a ser homologado judicialmente.

A transação penal pressupõe o acordo entre o Promotor de Justiça e o suposto autor do fato, acompanhado de seu defensor, em que não se pode compelir o representante ministerial a formular proposta se esse não é seu desiderato.

É antigo o entendimento jurisprudencial, ${ }^{70}$ no sentido de que cabe somente ao Ministério Público o oferecimento da proposta de transação penal, pois o Juiz ${ }^{71}$ não é o titular da ação penal e nem pode substituir-se ao representante ministerial para formular a proposta.

O instituto da suspensão condicional do processo, também denominado de sursis processual, caracteriza-se como uma medida despenalizadora, estabelecida por motivos de política criminal, com o objetivo de possibilitar, nos crimes em que a pena mínima cominada for igual ou inferior a um ano, que o processo nem chegue a se iniciar.

Nos crimes de lesão corporal culposa, decorrente de ato médico, o Promotor de Justiça, titular exclusivo da ação penal pública condicionada à representação, poderá propor a suspensão condicional do processo, por dois a quatro anos, desde que o

69 REAlE JÚNIOR, Miguel. Pena sem processo. In: PITOMBO, Antonio Sérgio A. de Moraes (Org.). Juizados especiais criminais: interpretação e crítica. São Paulo: Malheiros Ed., 1997. p. 26.

70 Vide, a título de exemplo: Cor. Par. n. 1.012.835/9, 12 ${ }^{\text {a }}$ Câm., Rel. Juiz Walter Guilherme, j. 17.6.96, v.u.

71 JARDIM, Afrânio Silva. Os princípios da obrigatoriedade e da indisponibilidade nos juizados especiais criminais. Boletim do IBCCRIM, São Paulo, n. 48, nov. 1996. p. 4. 
denunciado (médico) não esteja sendo processado ou não tenha sido condenado por outro crime, presentes os demais requisitos que autorizariam a suspensão condicional da pena (art. 77, do Código Penal).

Tal concessão ex officio, sem a anuência do Ministério Público, implicaria em se aceitar a legitimidade do Juiz para exercer função constitucionalmente acometida, afrontando um dos princípios fundamentais da processualística penal contemporânea, consubstanciado na ideia de um verdadeiro processo acusatório de partes.

No que diz respeito ao oferecimento da denúncia, para o início da ação penal, o representante ministerial deverá analisar os requisitos objetivos e subjetivos expressos no art. 89, da Lei n. 9.099/95, e, caso seja feita a proposta do sursis processual, em cota introdutória da peça exordial acusatória, requerer ao juízo as folhas de antecedentes criminais e certidões judiciais do que nelas eventualmente constar, para melhor análise dos requisitos subjetivos autorizadores do benefício.

O Promotor de Justiça, ao oferecer a denúncia em crime de lesão corporal culposa, decorrente de ato médico, deve se manifestar e fundamentar, adequada e concretamente, o oferecimento ou não da proposta de suspensão condicional do processo.

$\mathrm{Na}$ sistemática procedimental vigente, oferecida a denúncia pelo órgão ministerial, com a proposta de suspensão condicional do processo, o Juiz poderá recebê-la ou rejeitá-la, após verificar se estão presentes os pressupostos processuais, decisão cabível à luz do disposto no art. 395, do Código de Processo Penal, segundo o qual "A denúncia ou queixa será rejeitada quando: I - for manifestamente inepta; II - faltar pressuposto processual ou condição para o exercício da ação penal; ou III - faltar justa causa para o exercício da ação penal".

Recebendo a peça acusatória, o Juiz designará audiência específica para a formalização da proposta de suspensão condicional do processo, determinando a citação do médico para responder à acusação, por escrito, nos termos do art. 396, do Código de Processo Penal.

Desta forma, o Ministério Público, com o oferecimento da denúncia, apresenta a proposta de suspensão condicional do processo para o denunciado (médico), acompanhado de defensor, contendo as condições facultativas ${ }^{72}$ ou obrigatórias, tais como, a de reparação do dano, salvo a impossibilidade do denunciado fazê-lo; a proibição de frequentar lugares de má reputação; a proibição de se ausentar da Comarca onde reside, sem autorização do Juiz; além do comparecimento mensal, pessoal e obrigatório em juízo, para informar e justificar suas atividades.

72 Em relação as condições facultativas, vide: STF, HC n. 108.914/RS, Rel. Min., Rosa Weber. 
Em sendo aceita pelo médico, acompanhado de seu defensor, as condições estabelecidas na proposta ministerial, o Juiz homologa o acordo.

Após a homologação, o médico se submeterá a um período de prova (sobrestamento do feito), que pode durar entre dois e quatro anos, no qual o médico terá que cumprir as condições estabelecidas no acordo para, ao final, ser decretada a extinção da punibilidade.

Desta forma, a suspensão condicional do processo é um instituto de natureza processual, tendo efeitos penais: a extinção da punibilidade.

Somente ao final do período de prova, para fins de extinção da punibilidade, deverá o denunciado ter comprovado a reparação do dano.

Se durante o período probatório, o denunciado (médico) for processado por um novo delito ou descumprir as condições estabelecidas nos termos do acordo, a suspensão condicional do processo poderá ser revogada e, nessa hipótese, com o prosseguimento da ação penal.

Frustrada a fase de conciliação e não tendo sido aceita a proposta de transação penal pelo suposto autor do fato (médico), o Ministério Público oferecerá a denúncia oral, na própria audiência preliminar, desde que não existam novas diligências ou exames periciais a serem requisitados ou laudos técnicos a serem complementados, diante, muitas vezes, da complexidade probatória, na apuração do crime de lesão corporal culposa, decorrente de ato médico.

Não aceita a proposta de suspensão condicional do processo, a denúncia oral formulada pelo órgão ministerial será reduzida a termo, cuja cópia será entregue ao denunciado (médico), que ficará citado na própria audiência preliminar.

Nesta oportunidade ${ }^{73}$ o médico ficará ciente da designação de audiência de instrução e julgamento, da qual ficarão cientes o Ministério Público, a vítima (e se possível, o responsável civil) e advogados.

Instalada a audiência de instrução e julgamento, o Juiz esclarecerá sobre a possibilidade da conciliação, da composição civil dos danos e até mesmo da transação penal, caso não tenha sido oferecida, anteriormente, em virtude do não comparecimento do médico à audiência preliminar.

Não se efetivando qualquer acordo, será dada palavra ao advogado do médico para responder à acusação, pelo oferecimento de defesa oral, enfrentando diretamente a acusação pelo mérito ou processualmente, por preliminares ou questões

73 Se o médico não estiver presente nesta audiência, será citado por mandado e se não for localizado, os autos serão remetidos ao juízo comum. 
prévias que possam ensejar a rejeição da denúncia, ${ }^{74}$ evidenciando a falta dos pressupostos e das condições da ação penal ou absolvendo sumariamente o acusado.

$\mathrm{Na}$ audiência, após a defesa oral, realizado o juízo de admissibilidade da acusação, o Juiz ao receber a denúncia, procede à oitiva da vítima, das testemunhas e ao interrogatório do acusado e, após os debates orais, profere a sentença oral.

\section{Objetivo}

O objetivo desta dissertação é demonstrar a ineficiência da aplicação da Lei n. 9.099/95, no tocante ao crime de lesão corporal culposa decorrente de ato médico. Enfatiza-se que, na resolução dos procedimentos de infrações de menor potencial ofensivo, envolvendo a responsabilidade penal do médico, os operadores do direito avaliam superficialmente a conduta culposa deste profissional da área de saúde, diante da análise do termo circunstanciado, em procedimento sumaríssimo, no âmbito dos Juizados Especiais Criminais (JECrim), em que, a priori, procede-se a um juízo de culpa pessoal e, em muitos casos, na ocorrência de medidas alternativas à pena de prisão, sem a cautela de segurança jurídica quanto a sua aplicação.

Discute-se, ainda, a transação penal como medida de política criminal; bem como sua (in)constitucionalidade, em virtude de não se atentar para alguns princípios constitucionais, dentre os quais: devido processo legal, ampla defesa, contraditório e presunção de inocência.

\section{Método}

A presente dissertação foi desenvolvida a partir da investigação analítica e dogmática do Direito Penal Médico, tema pouco avançado na dogmática penal brasileira; mas que inspira pesquisadores no estrangeiro.

O Direito Penal Médico é uma importante área do Direito, que merece estudo e aprofundamento, principalmente no que se refere à responsabilidade penal

\footnotetext{
74 Vide, art. 395, do Código de Processo Penal, redação dada pela Lei n. 11.719, de 2008, em que a denúncia será rejeitada quando: "I - for manifestamente inepta; II - faltar pressuposto processual ou condição para o exercício da ação penal; ou III - faltar justa causa para o exercício da ação penal." Vide, também, o art. 82, da Lei n. 9.099/95: "Da decisão de rejeição da denúncia ou queixa e da sentença caberá apelação, que poderá ser julgada por turma composta de três Juízes em exercício no primeiro grau de jurisdição, reunidos na sede do Juizado. $\S 1^{\circ}$ A apelação será interposta no prazo de dez dias, contados da ciência da sentença pelo Ministério Público, pelo réu e seu defensor, por petição escrita, da qual constarão as razões e o pedido do recorrente. $\S 2^{\circ} \mathrm{O}$ recorrido será intimado para oferecer resposta escrita no prazo de dez dias. $\S 3^{\circ}$ As partes poderão requerer a transcrição da gravação da fita magnética a que alude o $\S 3^{\circ}$ do art. 65 desta Lei. $\S 4^{\circ}$ As partes serão intimadas da data da sessão de julgamento pela imprensa. $\S 5^{\circ}$ Se a sentença for confirmada pelos próprios fundamentos, a súmula do julgamento servirá de acórdão."
} 
dos médicos, diante das controvérsias que lhe são inerentes e que proporcionam debate frutífero sobre as possibilidades e limites desta matéria.

Em um primeiro momento, são pesquisados os aspectos históricos do crime de lesão corporal culposa, justapondo o Direito Penal e a Medicina, numa visão interdisciplinar e, tendo em vista que em sua atividade profissional, o médico se depara com situações nas quais pode ser responsabilizado penalmente, é necessário o estudo e a compreensão da aplicação da deontologia médica, do Código de Ética Médica, do ato médico e das leges artis.

A partir da ideia geral desse desenvolvimento, acrescente-se, a isso, a concatenação do método dialético no desenvolvimento posterior desta pesquisa, por meio de livros, alguns raros, aliados a artigos científicos e posições doutrinais modernas e atuais, para a melhor compreensão da teoria do crime culposo do ato médico e, na essência do trabalho, a responsabilidade penal do médico na Lei n. 9.099/95, no crime de lesão corporal culposa decorrente de ato médico.

Em razão disso, depreende-se a atualidade e a relevância do objeto de estudo.

Observe-se, ainda, que a pesquisa é de natureza teórico-bibliográfica, seguindo o método descritivo e analítico.

A investigação vincula-se, eminentemente, ao Direito Penal brasileiro, de aproximações com ciências afins e sem prejuízo do trabalho científico desenvolvido no panorama internacional.

\section{Conclusões}

1. Desde a Medicina arcaica, baseada na interpretação da doença como fenômeno sobrenatural e de concepção mítica, leis foram estabelecidas, traduzindo a vontade dos homens em punir o médico que desempenhasse mal a sua arte. Para bem compreendermos a responsabilidade penal do médico nessas sociedades primitivas, é necessário examiná-la no seu contexto social respectivo. No que se refere à responsabilidade penal médica no Código de Hamurabi, nos arts. 215 a 223, em que se disciplina a prática médica e a punição se apresenta como vingança pública, pela melhor interpretação destes dispositivos legais, que necessita ser contextualizada, os médicos não estavam sujeitos ao talião.

2. A teoria sobre o erro humano de James Reason, foi apresentada no ano de 1990, pela publicação do livro Human error. Dada a sua importância mundial, os estudos e pesquisas desenvolvidos por James Reason foram, recentemente, direcionados à área de saúde, avançando no conhecimento a respeito dos processos em que o erro humano se engendra e na aplicação prática de seus estudos, com o propósito de eliminar 
ou conter os efeitos adversos decorrentes desse erro, evidenciou as características do sistema de saúde que predispõem a ocorrência de falhas. Nessas circunstâncias, deve-se ter cautela quanto à questão da responsabilização penal do médico, muitas vezes, diante das fragilidades e deficiências nas barreiras de defesas do sistema de saúde por inteiro.

3. Um dos institutos inovadores da Lei n. 9.099/95, ainda, permanece polêmico: a transação penal, instituto novo e sem precedentes na história processual penal brasileira cuja interpretação dos seus dispositivos normativos é controversa. Confrontando as previsões legais com a realidade empírica de um novo modelo de Justiça penal, na análise da aplicação desse novel instituto, é de extrema relevância na investigação da lesão corporal culposa decorrente de ato médico, as implicações da adoção da transação penal ao considerado autor do fato (médico), segundo as regras de processo penal constitucional, sob pena de ferir direitos e garantias legalmente assegurados.

\section{Referências}

ALMEIDA JÚNIOR, A.; COSTA JÚNIOR, J. B. de O. e. Lições de medicina legal. 19. ed. rev. ampl. São Paulo: Companhia Editora Nacional, 1987.

ALMEIDA JUNIOR, João Mendes. O processo criminal brazileiro. 3. ed. Augmentada. Rio de Janeiro: Typ. Baptista de Souza, 1920. v. 2.

ALVES, Jeovanna Malena Viana Pinheiro. Ensaios clínicos. Coimbra: Coimbra Ed., 2003. (Faculdade de Direito da Universidade de Coimbra, Centro de Direito Biomédico, 8).

ANTUNES, João Lobo. Um modo de ser. 12. ed. Lisboa: Gradiva Publicações, 2003.

ARIAS MADRIGAL, Doris. La responsabilidad penal en el ámbito médico sanitario: algunas consideraciones generales. Revista de la Asociación Española de Ciencias Penales, Madrid, v. 2, n. $1,1999$.

AVECONE, Pio. La responsabilità penale del medico. Padova: Casa Editrice Dott. Francesco Vallardi, 1981.

AZARA, Antonio. Codice di Hammurabi. In: AZARA, Antonio; EULA, Ernesto (A cura di). Novissimo digesto italiano. Torino: UTET, 1967.

BECHARA, Ana Elisa Liberatore Silva. Bem jurídico-penal. São Paulo: Quartier Latin, 2014.

BÍBLIA Sagrada. Tradução Centro Bíblico Católico. 65. ed. São Paulo: Ave Maria, 1989.

BOBBIO, Norberto. Elogio da serenidade e outros escritos morais. Tradução de Marco Aurélio Nogueira. 2. ed. São Paulo: Ed. Unesp, 2011.

BRUNO, Aníbal. Direito penal: parte geral - introdução, norma penal, fato punível. 5. ed. rev. atual. Raphael Cirigliano Filho. Rio de Janeiro: Forense, 2005. t. 1. 
CARRARA, Francesco. Programa do curso de direito criminal: parte geral. Tradução de José Luiz de V. de A. Franceschini e J. R. Prestes Barra. São Paulo: Saraiva, 1956. v. 1.

CASTIGLIONI, Arturo. Storia della medicina. Verona: Mondadori, 1948.

CHAIA, Rubén A. Responsabilidad penal médica. Buenos Aires: Hammurabi, 2006.

CORRIGAN, Janet M.; DONALDSON, Molla S.; KOHN, Linda T. To err is human: building a safer health system. The Institute of Medicine (IOM). Washington, D.C: National Academy Press, 1999.

COSTA, José de Faria. Bioética e direito penal (reflexões possíveis em tempos de incerteza). Coimbra: Coimbra Editora, 2009. v. 1. (Boletim da Faculdade de Direito, Universidade de Coimbra. Ars Ivdicandi. Estudos em Homenagem ao Prof. Doutor Jorge de Figueiredo Dias).

DIAS, Hélio Pereira. A responsabilidade pela saúde: aspectos jurídicos. Rio de Janeiro: Fiocruz, 1995.

DIREITO, Carlos Alberto Menezes. Do erro médico. Revista de Direito da Upis, Brasília, v. 2, p. 101-110, set./dez. 2004.

DOTTI, René Ariel. Conceitos e distorções da Lei n. 9.099/95 - temas de direito e processo penal. In: PITOMBO, Antonio Sérgio A. de Moraes (Org.). Juizados especiais criminais: interpretação e crítica. São Paulo: Malheiros Ed., 1997.

ENGISCH, Karl. Der finale Handlungsbegriff. In: BOCKELMANN, Paul et al. (Ed.). Probleme der Strafrechtserneuerung: Festschrift für Eduard Kohlrausch. Berlin: Walter de Gruyter, 1944.

ESER, Albin. Perspectivas do direito (penal) da medicina. Revista Portuguesa de Ciência Criminal, Coimbra, ano 14, n. 1/2, jan./jun., 2004.

FARIA, José Eduardo. As transformações do direito. Revista Brasileira de Ciências Criminais, São Paulo, ano 6, n. 22, abr./jun., 1998.

FERRI, Enrico. Princípios de direito criminal: o criminoso e o crime. Tradução de Luiz de Lemos D’Oliveira. 3. ed. Campinas: Russell Editores, 2009.

FRAGOSO, Heleno Cláudio. Lições de direito penal: parte geral. 17. ed. atual. Fernando Fragoso. Rio de Janeiro: Forense, 2006.

GARCIA, Basileu. Instituições de direito penal. 6. ed. São Paulo: Max Limonad, 1982. v. 1, t. 1.

GÓMEZ RIVERO, Maria Del Carmen. La responsabilidad penal del médico. 2. ed. Valencia: Tirant lo Blanch, 2008.

GORANSKY, Mirna. Criterios jurisprudenciales en el ámbito de la imprudencia de la actividad médica. In: MAIER, Julio B. J. (Comp.). Cuestiones particulares de la imprudencia en el derecho penal. Buenos Aires: Ad-Hoc, 1999. 
GRINOVER, Ada Pellegrini; GOMES FILHO, Antônio Magalhães; FERNANDES, Antônio Scarance; GOMES, Luiz Flávio. Juizados especiais criminais: comentários à Lei 9.099, de 26.09.1995. São Paulo: Ed. Revista dos Tribunais, 1996.

JARDIM, Afrânio Silva. Direito processual penal. 11. ed. Rio de janeiro: Forense, 2007.

JARDIM, Afrânio Silva. Os princípios da obrigatoriedade e da indisponibilidade nos juizados especiais criminais. Boletim do IBCCRIM, São Paulo, n. 48, nov. 1996.

JIMÉNEZ ASÚA, Luís. Tratado de derecho penal. 3. ed. Buenos Aires: Losada, 1976. t. 4.

JUNG, Heike. Introduction au droit médical allemand. Revue de Science Criminelle et de Droit Pénal Comparé, Paris, v. 1, janv./mars. 1996.

LEME, Pedro de Alcântara da Silva. O erro médico e suas implicações penais e civis. Revista Brasileira de Ciências Criminais, São Paulo, ano 1, n. 1, jan./mar. 1993.

MANZINI, Vincenzo. Tratado de derecho penal: teorías generales. Traducción de Santiago Sentís Melendo. Buenos Aires: Ediar Editores, 1948. v. 1. t. 1.

MARQUES, José Frederico. Elementos de direito processual penal. 2. ed. Rio de Janeiro: Forense, 1965. v. 1.

MONZHEIN, Paul. A responsabilidade penal do médico. Tradução de Alcides Amaral Salles. Revista Justitia, São Paulo, ano 35, v. 81, 2. trim., 1973.

MORAES, Irany Novah. Erro médico. 2. ed. ampl. São Paulo: Ed. Santos-Maltese, 1991.

MORAES FILHO, Antonio Evaristo de. Aspectos da responsabilidade penal do médico. Revista da Faculdade de Direito da UERJ, Rio de Janeiro, n. 4, 1996.

MORIN, Edgard. Ciência com consciência. Tradução Maria D. Alexandre e Maria Alice Sampaio Dória. 8. ed. Rio de Janeiro: Bertrand Brasil, 2005.

NORONHA, Edgard Magalhães. Direito penal: introdução e parte geral. 24. ed. atual. Adalberto José Q. T. Camargo Aranha. São Paulo: Saraiva, 1986.

NORONHA, Edgard Magalhães. Do crime culposo. São Paulo: Saraiva, 1957.

OLIVEIRA, José de Alcântara Machado de. Arquivo de medicina legal e identificação. São Paulo: [s.n.], n. 12, 1935.

PASCHOAL, Janaína Conceição. Constituição, criminalização e direito penal mínimo. São Paulo: Revista dos Tribunais, 2003.

PETROCELLI, Biaggio. Principi di diritto penale. Napoli: Jovene, 1964. t. 1.

PIERANGELI, José Henrique. O consentimento do ofendido: na teoria do delito. 3. ed. rev. e atual. São Paulo: Ed. Revista dos Tribunais, 2001. 
PIERANGELI, José Henrique. Escritos jurídico-penais. 3. ed. rev. atual. e ampl. São Paulo: Ed. Revista dos Tribunais, 2006.

RAPOSO, Vera Lúcia. Do ato médico ao problema jurídico: breves notas sobre o acolhimento da responsabilidade médica civil e criminal na jurisprudência nacional. Coimbra: Almedina, 2013.

REALE JÚNIOR, Miguel. Instituições de direito penal: parte geral. 2. ed. Rio de Janeiro: Forense, 2006. v. 1.

REALE JÚNIOR, Miguel. Pena sem processo. In: PITOMBO, Antonio Sérgio A. de Moraes (Org.). Juizados especiais criminais: interpretação e crítica. São Paulo: Malheiros Ed., 1997.

REALE JÚNIOR, Miguel. Teoria do delito. 2. ed. rev. São Paulo: Revista dos Tribunais, 2000.

REASON, James. El error humano. Madrid: Modus Laborandi, 2009.

RODRIGUES, Álvaro da Cunha Gomes. A negligência médica hospitalar na perspectiva jurídicopenal: estudo sobre a responsabilidade criminal médico-hospitalar. Coimbra: Almedina, 2013.

ROMEO CASABONA, Carlos María. El médico y el derecho penal I: la actividad curativa (Licitud y responsabilidad penal). Barcelona: Ed. Bosch, 1981.

ROXIN, Claus. Derecho penal: parte general. Madrid: Civitas, 1997. t. 1.

RUNCIMAN, W. et al. Towards an international classification for patient safety: key concepts and terms. International Journal for Quality in Health Care, Oxford, v. 21, n. 1, 2009.

SÁ, Elida Lúcia Batista. Iatrogenia e o erro médico sob a óptica jurídica. Revista de Direito da Defensoria Pública, Rio de Janeiro, a. 7, n. 10, mar. 1997.

SALVADOR NETTO, Alamiro Velludo. Finalidades da pena: conceito material de direito e sistema penal integral. São Paulo: Quartier Latin, 2009.

SCLIAR, Moacyr. A paixão transformada: história da medicina na literatura. São Paulo: Companhia das Letras 2005.

SCHMIDT, Eberhard. Der Arzt im Strafrecht. Leipzig: Verlag von Theodor Weicher, 1939.

TAVARES, Juarez. Direito penal da negligência: uma contribuição à teoria do crime culposo. 2. ed. rev. e ampl. Rio de Janeiro: Lumen Juris, 2003.

TAVARES, Juarez. Teoria do injusto penal. 3. ed. rev. ampl. Belo Horizonte: Del Rey, 2003.

TELLES JUNIOR, Goffredo da Silva. Palavras do amigo aos estudantes de direito: bosquejos extracurriculares, proferidos no escritório do professor em 2002. São Paulo: Juarez de Oliveira, 2003.

TOLEDO, Francisco de Assis. Erro no direito penal. São Paulo: Saraiva, 1977.

WELZEL, Hans. Derecho penal alemán. Santiago de Chile: Jurídica de Chile, 1987.

ZAFFARONI, Eugenio Raúl; PIERANGELI, José Henrique. Manual de direito penal brasileiro: parte geral. 7. ed. rev. e atual. 2. tir. São Paulo: Ed. Revista dos Tribunais, 2008. v. 1. 